\title{
SEEDING DENSITY IS A CRUCIAL DETERMINANT FOR THE IN VIVO VASCULARISATION CAPACITY OF ADIPOSE TISSUE-DERIVED MICROVASCULAR FRAGMENTS
}

\author{
T. Später ${ }^{1, *}$, C. Körbel ${ }^{1}$, F.S. Frueh ${ }^{1,2}$, R.M. Nickels ${ }^{1}$, M.D. Menger ${ }^{1}$ and M.W. Laschke ${ }^{1}$ \\ ${ }^{1}$ Institute for Clinical and Experimental Surgery, Saarland University, 66421 Homburg/Saar, Germany \\ ${ }^{2}$ Division of Plastic Surgery and Hand Surgery, University Hospital Zurich, 8091 Zurich, Switzerland
}

\begin{abstract}
Adipose tissue-derived microvascular fragments (ad-MVF) represent effective vascularisation units for the seeding of dermal substitutes. However, particularly in case of extensive skin defects, the required amounts of donor fat tissue for the harvesting of ad-MVF may not always be available. Therefore, we herein determined the lowest ad-MVF density needed to induce a sufficient vascularisation and incorporation of seeded implants. Collagen-glycosaminoglycan matrices (Integra ${ }^{\circledR}$; diameter: $4 \mathrm{~mm}$ ) were seeded with 15,000 (HD), 10,000 (MD) and 5,000 (LD) ad-MVF and implanted into full-thickness skin defects within mouse dorsal skinfold chambers, to analyse their in vivo vascularisation and incorporation. Intravital fluorescence microscopy showed a comparable vascularisation of HD and MD ad-MVF-seeded Integra ${ }^{\circledR}$, which was significantly higher when compared to LD ad-MVF-seeded Integra ${ }^{\circledR}$. As assessed by photoacoustic imaging, this was associated with an increased oxygenation of the implants. Additional histological and immunohistochemical analyses revealed an enhanced cellular infiltration, collagen content, microvessel density and epithelialisation of HD and MD ad-MVF-seeded Integra ${ }^{\circledR}$, indicating a better incorporation compared to LD ad-MVF-seeded implants. These findings demonstrate that $80,000 \mathrm{ad}-\mathrm{MVF} / \mathrm{cm}^{2}$ is the least required density to guarantee an effective vascularisation of the dermal substitute.
\end{abstract}

Keywords: Integra ${ }^{\circledR}$, dermal substitute, skin, tissue engineering, wound healing, vascularisation, photoacoustic imaging, dorsal skinfold chamber.

*Address for correspondence: Matthias W. Laschke, M.D., PhD, Institute for Clinical and Experimental Surgery, Saarland University, 66421 Homburg/Saar, Germany.

Telephone: $+4968411626554 \quad$ Fax: $+4968411626553 \quad$ Email: matthias.laschke@uks.eu

\section{Introduction}

For the treatment of extensive skin defects, autologous split-thickness skin grafting (STSG) is the method of choice (Kneilling et al., 2011; Kanapathy et al., 2016). However, particularly deep burn wounds, that exceed $50-60 \%$ of the total body surface, bear the risk of extensive scarring and donor site shortage for skin transplantation (MacNeil, 2007; Böttcher-Haberzeth et al., 2010; Shevchenko et al., 2010; Miyanaga et al., 2016). Moreover, the destruction of dermal and subcutaneous layers in deep wounds complicates the initial application of STSG and increases the risk of infection due to the loss of the skin's physiological barrier function.

To overcome these problems, several acellular matrices, such as Dermagraft ${ }^{\circledR}$ (Organogenesis Inc.) or Integra ${ }^{\circledR}$ (Integra Life Sciences), have been bioengineered as off-the-shelf products for the initial coverage of extensive dermal defects (Zhong et al., 2010; Graham et al., 2013; Debels et al., 2015;
Singer et al., 2015). As these dermal substitutes degrade over time, their porous structures not only provide mechanical support, but also promote cellular infiltration and vascular ingrowth from the surrounding host tissue, leading to a vascularised wound bed for the final coverage with STSG (Awad et al., 2000) after 3 weeks.

Experimental studies indicate that the incorporation of dermal substitutes is improved by the seeding with mesenchymal stem cells, keratinocytes and adipose tissue-derived microvascular fragments (ad-MVF) (Wisser and Steffes, 2003; Trottier et al., 2008; Frueh et al., 2017a). Of interest, ad-MVF can be isolated in large amounts from fat tissue within a short time and represent fully functional vessel segments (Frueh et al., 2017b). Hence, they bear the major advantage that their reassembly into new microvascular networks induces a rapid implant vascularisation and blood perfusion (Laschke et al., 2012; Laschke and Menger, 2015). For this purpose, angiogenic sprouts, growing out of the vessel 
segments, have to develop interconnections (Nunes et al., 2010). Since the growth rate of such angiogenic sprouts is $\sim 5 \mu \mathrm{m} / \mathrm{h}$ (Utzinger et al., 2015), the distance between individual ad-MVF crucially determines the kinetics of this network formation process (Später et al., 2017). These considerations suggest that a high seeding density of ad-MVF markedly contributes to the success of this vascularisation strategy. On the other hand, it should be noted that, particularly in case of large tissue defects, this would require large volumes of donor fat tissue, which may not always be available under clinical conditions.

Taking this into account, the aim of the present experimental study was to determine the lowest ad-MVF density needed to develop a sufficient vascularisation and incorporation of seeded implants. For this purpose, we performed an in-depth analysis to assess the number of ad-MVF that can be isolated from $1 \mathrm{~mL}$ of epididymal fat tissue of donor mice in dependency of their age. In addition, collagen-glycosaminoglycan matrices $\left(\right.$ Integra $^{\circledR}$ ) were seeded with three different ad-MVF densities and subsequently implanted into fullthickness skin defects within mouse dorsal skinfold chambers. Their vascularisation and incorporation was analysed throughout a 2-week observation period using intravital fluorescence microscopy, ultrasound and photoacoustic imaging, histology and immunohistochemistry.

\section{Materials and Methods}

\section{Animals}

All animal experiments were approved by the local governmental animal care committee (permit number: 33/2016) and conducted in accordance with the European legislation on the protection of animals (Directive 2010/63/EU) and the National Institutes of Health (NIH) guidelines on the care and use of laboratory animals (NIH publication \#85-23 Rev. 1985).

Dorsal skinfold chambers were implanted in wild-type C57BL/6 mice (Institute for Clinical and Experimental Surgery, Saarland University, Homburg, Germany), with an age of 4-6 months and a body weight of 24-28 g. Epididymal fat was isolated from male green fluorescent protein (GFP) ${ }^{+}$ mice [C57BL/6-Tg(CAG-EGFP)1Osb/J; The Jackson Laboratory, Bar Harbor, ME, USA], with an age of 7-12 months and a body weight of $>30 \mathrm{~g}$, to guarantee large epididymal fat pads containing sufficient amounts of ad-MVF for the seeding of the matrices (Grässer et al., 2016). The animals were housed under a $12 \mathrm{~h}$ light/dark cycle and received ad libitum water and standard food pellets (Altromin, Lage, Germany).

\section{Isolation of ad-MVF}

Ad-MVF were isolated from epididymal fat pads of $\mathrm{GFP}^{+}$donor mice, as previously described in detail (Frueh et al., 2017b). Briefly, the bilateral epididymal fat pads were transferred into $10 \%$ Dulbecco's modified eagle medium (DMEM; $100 \mathrm{U} / \mathrm{mL}$ penicillin, $0.1 \mathrm{mg} / \mathrm{mL}$ streptomycin; Biochrom, Berlin, Germany) and washed thrice with phosphate-buffered saline (PBS). Next, the isolated fat tissue was minced and digested for 10 min with collagenase NB4G (0.5 U/ $\mathrm{mL}$; Serva, Heidelberg, Germany) under slow stirring and humidified atmospheric conditions $\left(37^{\circ} \mathrm{C}\right.$, $5 \% \mathrm{CO}_{2}$ ). The digestion was neutralised with PBS supplemented with $20 \%$ foetal calf serum (FCS) and the cell-vessel suspension was incubated at $37^{\circ} \mathrm{C}$ for $5 \mathrm{~min}$. The fat supernatant was removed, the remaining suspension was filtered through a $500 \mu \mathrm{m}$ mesh and the $\mathrm{GFP}^{+}$ad-MVF were enriched up to a pellet size by a 5 min centrifugation at $120 \times g$. Subsequently, this ad-MVF pellet was either used for in vitro analyses or resuspended in $1 \mu \mathrm{L}$ of $0.9 \% \mathrm{NaCl}$ for the seeding of the implants.

\section{Quantification and length distribution of isolated ad-MVF}

Donor mice for the isolation of ad-MVF were assigned to 6 age groups $(7,8,9,10,11$ and 12 months old). To correlate the parameters animal age, fat tissue volume and ad-MVF number and size, ad-MVF were isolated from the epididymal fat pads of 18 donor mice ( $n=3$ per group). After isolation, $10 \%$ of the total cell-vessel suspension was diluted $1: 10$ in PBS and $100 \mu \mathrm{L}$ of this dilution were transferred into a 96-well plate to assess the number of ad-MVF by means of microscopic counting (Fig. 1a,b). The total number of ad-MVF was subsequently extrapolated to the whole isolate (Frueh et al., 2017b). Furthermore, the average ad-MVF length was measured by means of microscopic analysis.

\section{Flow cytometry}

To analyse the cellular composition of ad-MVF from 6 donor age groups $(7,8,9,10,11$ and 12 months old) by means of flow cytometry, ad-MVF, isolated from 18 male C57BL/ 6 mice ( $n=3$ per group), were digested for $30 \mathrm{~min}$ in Accutase ${ }^{\circledR}$ (BioLegend, Fell, Germany) to single cells. Then, the single cells were analysed for the expression of the monoclonal rat anti-mouse endothelial cell marker CD31-phycoerythrin (PE) (BD Biosciences, Heidelberg, Germany), the perivascular cell marker mouse anti- $\alpha$-smooth muscle actin (SMA) (Thermo Fisher Scientific Inc., Waltham, MA, USA), the monoclonal stromal/stem cell surface markers rat anti-mouse CD117-fluorescein isothiocyanate (FITC) (BD Biosciences), the mouse anti-rat/mouse CD90FITC (BioLegend) and the hamster anti-rat/mouse CD29-FITC (BioLegend). Isotype identical rat IgG-PE or rat IgG-FITC (BD Biosciences), mouse IgG-FITC (BD Biosciences) and hamster IgG-FITC (BioLegend) served as controls. Additionally, cells were analysed for the expression of the purified polyclonal sheep anti-mouse/human adipocyte marker adipocytespecific adhesion molecule (ASAM) (R\&D Systems, Wiesbaden, Germany), followed by a secondary donkey anti-sheep IgG-Alexa488 antibody (Molecular 

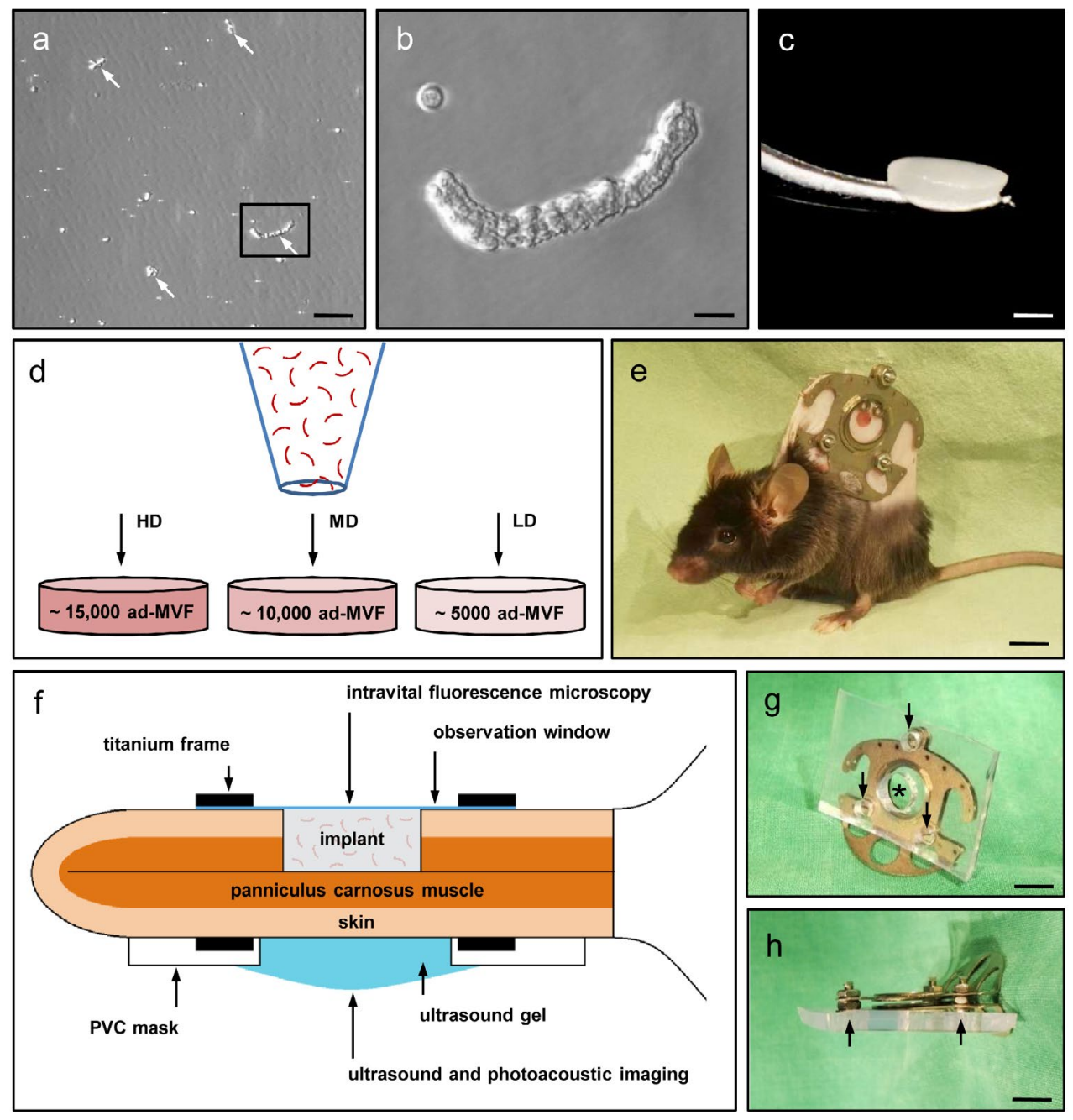

Fig. 1. Freshly isolated (a, arrows) ad-MVF from the epididymal fat pads of donor mice. Higher magnification $(\mathbf{b}=$ insert in $\mathbf{a})$ reveals a typical tube-like vessel morphology. Scale bars: $\mathbf{a}=100 \mu \mathrm{m}$; $\mathbf{b}=15 \mu \mathrm{m}$. (c) Integra ${ }^{\circledR}$ directly after sample preparation. Scale bar: $1.5 \mathrm{~mm}$. (d) The samples were seeded with a high density (HD), medium density (MD) and low density (LD) of ad-MVF. (e) C57BL/6 mouse with a dorsal skinfold chamber. Scale bar: $12 \mathrm{~mm}$. (f) Schematic cross-section of a dorsal skinfold chamber preparation with a full-thickness skin defect filled with ad-MVF-seeded Integra ${ }^{\circledR}$ (implant). The observation window provided direct access to the implant for repetitive intravital fluorescence microscopy, whereas ultrasound and photoacoustic imaging was performed from the backside of the chamber, which was covered with a PVC mask to prevent noise signal originating from the titanium frame. (g,h) Backside titanium frame of the chamber covered with a PVC mask (arrows = gaps for screws of the titanium frame; asterisk $=$ opening for photoacoustic imaging). Scale bars: $\mathbf{g}=10 \mathrm{~mm}, \mathbf{h}=6 \mathrm{~mm}$.

Probes, Eugene, OR, USA). Flow cytometric analyses were performed, using a FACScan (BD Biosciences) and data were assessed using the software package Cell-Quest Pro (BD Biosciences).

\section{Seeding of Integra ${ }^{\circledR}$}

A $4 \mathrm{~mm}$ biopsy punch (kaiEurope $\mathrm{GmbH}$, Solingen, Germany) was used to cut $12.6 \mathrm{~mm}^{2}$ identical implants out of a $1.3 \mathrm{~mm}$ thick Integra ${ }^{\circledR}$ dermal regeneration template single layer without silicone sheet (Integra Life Sciences, Ratingen, Germany). The samples (Fig. 1c) were placed on a $500 \mu \mathrm{m}$ cell strainer and $15 \mu \mathrm{L}$ of $0.9 \% \mathrm{NaCl}$, containing a high density (HD) of $\sim 15,000$ ad-MVF, a medium density (MD) of $\sim 10,000$ ad-MVF or a low density (LD) of $\sim 5,000$ ad-MVF (Fig. 1d), were transferred onto the implants with a $20 \mu \mathrm{L}$ pipette (Eppendorf, Wesseling-Berzdorf, Germany). Noteworthy, the used ad-MVF seeding density of the HD group was identical to that applied in previous studies (Frueh et al., 2017a).

\section{Modified dorsal skinfold chamber model}

According to Sorg et al. (2007; 2009), a modified dorsal skinfold chamber model was used for the in vivo analysis of ad-MVF-seeded implants (Fig. 1e). For the implantation of the dorsal skinfold chamber (Irola Industriekomponenten $\mathrm{GmbH} \& \mathrm{Co}$. KG, Schonach, Germany), the mice were anaesthetised by intraperitoneal injection of ketamine $(75 \mathrm{mg} / \mathrm{kg}$ body weight; Ursotamin ${ }^{\circledR}$; Serumwerke Bernburg, Bernburg, Germany) and xylazine ( $15 \mathrm{mg} / \mathrm{kg}$ body weight; Rompun ${ }^{\circledR}$; Bayer, Leverkusen, Germany). 
Then, the two symmetrical titanium frames were fixed on the extended dorsal skinfold, as described previously in detail (Laschke and Menger, 2016). After a $48 \mathrm{~h}$ recovery period, the mice were anaesthetised again and a $4 \mathrm{~mm}$ full-thickness skin defect was created within the observation window of the chamber using a dermal biopsy punch (kaiEurope $\mathrm{GmbH}$ ) and microsurgical instruments. Subsequently, the defect was filled with ad-MVFseeded Integra ${ }^{\circledR}$ before the observation window of the chamber was sealed with a removable cover glass (Fig. 1f).

\section{Stereomicroscopy}

To assess the epithelialisation of ad-MVF-seeded Integra $^{\circledR}$, as well as the implant-induced degree of haemorrhage by planimetry, the anaesthetised animals were fixed on a Plexiglas ${ }^{\circledR}$ stage and the dorsal skinfold chamber was positioned under a stereomicroscope (Leica M651, Wetzlar, Germany) on day 0 (day of implantation), 3, 6, 10 and 14. The chamber tissue was visualised in epi-illumination to identify epithelialised and non-epithelialised implant areas. Furthermore, trans-illumination was used to evaluate the extent of bleeding induced by implanted HD, MD and LD ad-MVF-seeded Integra ${ }^{\circledR}$ (given in \% of implant surface) by means of a semi-quantitative haemorrhagic score as follows: 1: no bleeding, 2: 1-25\%, 3: 26-50 \%, 4: 51-75 \%, 5: 76-100 \%, 6: bleeding exceeding implant surface. The microscopic images were recorded by a DVD system and analysed using the CapImage computer-assisted off-line analysis system (Zeintl, Heidelberg, Germany). The epithelialised area (given in \%) was calculated by the equation: (total implant area - non-epithelialised implant area) / (total implant area) $\times 100$ (Später et al., 2016).

\section{Intravital fluorescence microscopy}

After stereomicroscopy, $0.1 \mathrm{~mL}$ of the blood plasma marker FITC-labelled dextran (5\%; 150,000 Da;SigmaAldrich, Taufkirchen, Germany) was retrobulbarily injected into the venous plexus of the anaesthetised animals for contrast enhancement. The observation window of the chamber was positioned under a Zeiss Axiotech fluorescent microscope (Zeiss, Oberkochen, Germany) and the microscopic images were recorded by a charge-coupled device video camera (FK6990; Pieper, Schwerte, Germany) and a DVD system for off-line analyses (Laschke et al., 2015).

The analysis of the microscopic images was performed using CapImage (Zeintl). The vascularisation of the implants was assessed in 12 regions of interest (ROIs). ROIs exhibiting red blood cell (RBC)-perfused microvessels were defined and counted as perfused ROIs (in \% of all ROIs) (Später et al., 2017). The functional microvessel density was determined as the total length of all RBC-perfused microvessels per ROI $\left(\mathrm{cm} / \mathrm{cm}^{2}\right)$. In addition, the diameter $(d$, in $\mu \mathrm{m})$ and centreline RBC velocity $(v$, $\mu \mathrm{m} / \mathrm{s}$ ) of 40 randomly selected microvessels were measured. Subsequently, these two parameters were used to calculate the wall shear rate $\left(y\right.$, in s $\left.^{-1}\right)$ by means of the Newtonian definition $y=8 \times v / d$ (Ampofo et al., 2016).

\section{Ultrasound and photoacoustic imaging}

Ultrasound and photoacoustic imaging was used to detect haemoglobin oxygen saturation $\left(\mathrm{sO}_{2}\right)$ in OxyHemo-mode within HD, MD and LD ad-MVFseeded Integra ${ }^{\circledR}$ by using a Vevo LAZR system (FUJIFILM VisualSonics Inc., Toronto, ON, Canada) and a real-time microvisualisation LZ550 linear-array transducer (FUJIFILM VisualSonics Inc.) with a centre frequency of $40 \mathrm{MHz}$.

For in vitro analyses, freshly-seeded, nonimplanted Integra ${ }^{\circledR}$ samples were embedded in ultrasound gel (Aquasonic 100; Parker, Fairfield, NJ, USA) to prevent interference with ultrasound coupling. For the in vivo analysis of implanted Integra ${ }^{\circledR}$ on day 14 , the chamber-equipped animals were anaesthetised with $1.5 \%$ isofluorane in air and subsequently fixed in prone position on a heated stage. Heart rate and breathing rate were constantly monitored and the body temperature was maintained at $37{ }^{\circ} \mathrm{C}$ (THM100; Indus Instruments, Houston, TX, USA). To prevent noise signal originating from the titanium frames, the dorsal skinfold chamber was covered with a $3 \mathrm{~mm}$ soft polyvinyl chloride (PVC) mask (Fig. 1g,h; Sagustu International $\mathrm{GmbH}$, Bruchmühlbach-Miesau, Germany) and the depilated skin, within the backside of the observation window, was covered with ultrasound gel to avoid air interference with ultrasound coupling into the animal.

For three-dimensional, high-resolution B-mode ultrasound and OxyHemo-mode photoacoustic image acquisition, the scanhead was driven by a linear motor to acquire two-dimensional images at regular spatial intervals, parallel and uniformly spaced at $150 \mu \mathrm{m}$ intervals over the entire implant diameter. OxyHemo-mode photoacoustic images were taken at $750 \mathrm{~nm}$ and $850 \mathrm{~nm}$ with a two-dimensional gain of $34 \mathrm{~dB}$ (in vitro) and $32 \mathrm{~dB}$ (in vivo) to detect $\mathrm{sO}_{2}$ within the samples (Mallidi et al., 2015; Rich and Seshadri, 2015). All values were acquired using the Vevo LAB 1.7.2. software (FUJIFILM VisualSonics Inc.).

\section{Experimental protocol}

In a first set of experiments, the volume of the excised epididymal fat tissue from the $18 \mathrm{GFP}^{+}$donor mice of the 6 different age groups $(7,8,9,10,11$ and 12 months old; $n=3$ per group) was quantified. Subsequently, both the number of ad-MVF per $\mathrm{mL}$ fat tissue, as well as, the ad-MVF length were assessed by means of microscopic analysis. The cellular composition of ad-MVF after isolation was investigated by additional flow cytometric analyses.

For in vivo analyses, ad-MVF were harvested from the epididymal fat tissue of $8 \mathrm{GFP}^{+}$donor mice. The isolated ad-MVF were divided into 3 different density groups (HD: 15,000 ad-MVF; MD: 10,000 

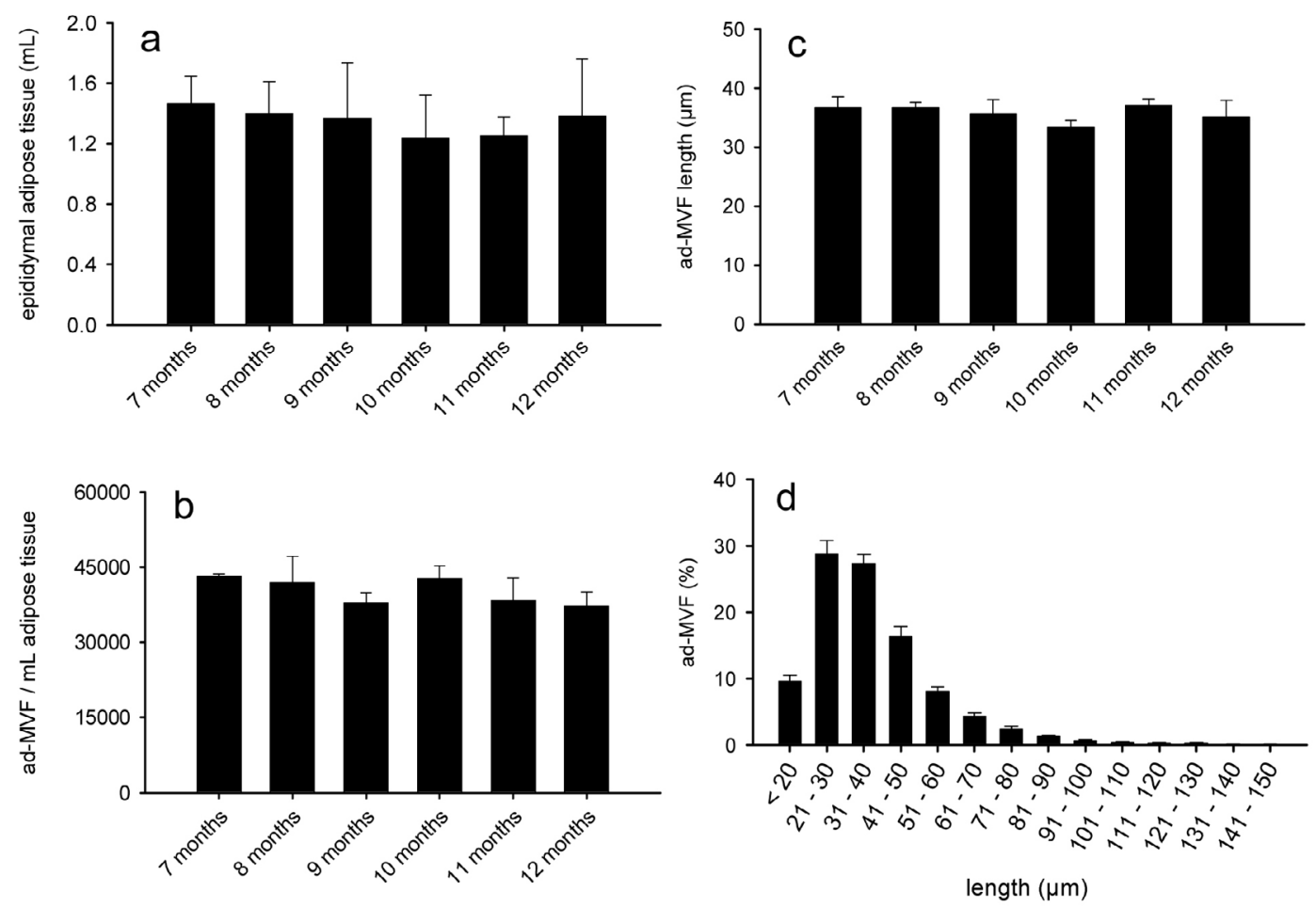

Fig. 2. (a) Volume of available epididymal adipose tissue (in $\mathrm{mL}$ per animal), (b) number of isolated ad-MVF (per mL adipose tissue) and (c) average ad-MVF length $(\mu \mathrm{m})$ from 7, 8, 9, 10, 11 and 12 months old $\mathrm{GFP}^{+}$donor mice ( $n=3$ per group). Mean \pm SEM. (d) Length distribution of ad-MVF (\%) from 7-12 months old $\mathrm{GFP}^{+}$donor mice $(n=18)$. Mean \pm SEM.

ad-MVF; LD: 5,000 ad-MVF) and subsequently seeded on Integra ${ }^{\circledR}(n=8$ per group). The seeded matrices were implanted into full-thickness skin defects within dorsal skinfold chambers of $24 \mathrm{GFP}^{-}$ wild-type C57BL/6 recipient animals. Vascularisation, incorporation, epithelialisation and bleeding of the implants were analysed by means of repetitive stereomicroscopy and intravital fluorescence microscopy on day 0 (day of implantation), 3, 6, 10 and 14. Finally, ultrasound and photoacoustic imaging of 3 implants per group was performed on day 14 . Thereafter, the animals were sacrificed with an overdose of anaesthesia and the dorsal skinfold chamber preparations were processed for histological and immunohistochemical analyses.

\section{Histology and immunohistochemistry}

Formalin-fixed samples of the dorsal skinfold preparations with the implants were embedded in paraffin and subsequently cut into $3 \mu \mathrm{m}$-thick sections. Haematoxylin and eosin (HE) staining of individual sections was performed according to standard procedures. In addition, the reddish appearance, under polarised light, of mature sirius red-stained collagen type I fibres was used to quantify the collagen content of implanted ad-MVF-seeded Integra ${ }^{\circledR}$. The collagen content was assessed in relation to normal skin in 4 central ROIs for each sample using a BX60 microscope (Olympus, Hamburg, Germany) and the imaging software cellSens Dimension 1.11 (Olympus) (Frueh et al., 2017a).
Additional sections were co-stained using a monoclonal rat anti-mouse antibody against the endothelial cell marker CD31 (1 : 100; Dianova, Hamburg, Germany) and a polyclonal goat antibody against GFP (1 : 200; Rockland Immunochemicals, Limerick, PA, USA) while a goat anti-rat IgG Alexa555 ( 1 : 200; Life Technologies, Ober-Olm, Germany) and a biotinylated donkey anti-goat antibody (1:30; Dianova) served as secondary antibodies. The biotinylated antibody was detected by streptavidinAlexa488 (1 : 50; Life Technologies) and cell nuclei were stained with Hoechst 33342 (1 : 500; SigmaAldrich). The density of $\mathrm{CD} 31^{+}$microvessels (given in $\mathrm{mm}^{-2}$ ) and the fraction of $\mathrm{CD} 31^{+} / \mathrm{GFP}^{+}$microvessels (given in \%) were quantitatively analysed within the implants.

For the immunohistochemical detection of the cytokeratin $^{+}$epithelial layer, covering the implanted Integra $^{\circledR}$ on day 14 , sections of the largest crosssectional diameter of the matrices were incubated with a rabbit polyclonal anti-cytokeratin antibody (1 : 100; Abcam, Cambridge, UK), as primary antibody, followed by a biotinylated goat antirabbit IgG antibody (ready-to-use; Abcam). The biotinylated antibody was detected by peroxidaselabelled-streptavidin (1:50; Sigma-Aldrich) and 3,3-diaminobenzidine (Sigma-Aldrich) was used as chromogen. Using a BZ-8000 microscopic system (Keyence, Osaka, Japan), the length of the cytokeratin ${ }^{+}$ epithelial layer and the diameter of the implants were measured to assess epithelialisation as: length 
of cytokeratin ${ }^{+}$epithelial layer / total diameter of implant $\times 100$.

For the immunohistochemical detection of myeloperoxidase (MPO) ${ }^{+}$neutrophilic granulocytes, $\mathrm{CD}^{+} 8^{+}$macrophages and $\mathrm{CD}^{+}$lymphocytes, sections were incubated with a rabbit polyclonal anti-MPO antibody (1: 100; Abcam), a rabbit polyclonal antiCD68 antibody (1:50; Abcam) and a rabbit polyclonal anti-CD3 antibody (1 : 100; Abcam), as primary antibodies, followed by a biotinylated goat anti-rabbit IgG antibody (ready-to-use; Abcam). The biotinylated antibody was detected by peroxidase-labelledstreptavidin (1 : 50; Sigma-Aldrich). 3-Amino-9ethylcarbazole (Abcam) was used as chromogen. The sections were counterstained with Mayer's haemalum (Merck, Darmstadt, Germany) and the number of immune cells (given in $\mathrm{mm}^{-2}$ ) was quantitatively assessed in 6 ROIs per section by light microscopy (BX60).

\section{Statistical analysis}

After testing the data for normal distribution and equal variance, differences between the groups were analysed by ANOVA followed by the StudentNewman-Keuls post hoc test. In case of non-parametric data, differences were assessed by ANOVA on Ranks, followed by the Dunn's post hoc test (SigmaPlot 11.0; Jandel Corporation, San Rafael, CA, USA). All values were expressed as mean \pm standard error of the mean (SEM). Statistical significance was accepted for a value of $p<0.05$.

\section{Results}

\section{Quantification, length distribution and cellular composition of ad-MVF}

There were no significant differences in the available volume of epididymal adipose tissue from donor mice in the age range of 7-12 months (Fig. 2a). In all analysed groups, $\sim 1.4 \mathrm{~mL}$ adipose tissue could be harvested for the subsequent isolation of ad-MVF. From this amount of tissue, an overall number of $\sim 40,000$ ad-MVF per $\mathrm{mL}$ with an average length of $\sim 40 \mu \mathrm{m}$ could be enzymatically isolated (Fig. 2 b,c). More detailed analyses revealed that $73 \%$ of the isolated ad-MVF from all 6 age groups exhibited a length of 21-50 $\mu \mathrm{m}$ (Fig. 2d). Additional flow cytometric analyses showed a comparable cellular composition of ad-MVF from the donor animals of the different ages (Table 1). Ad-MVF typically

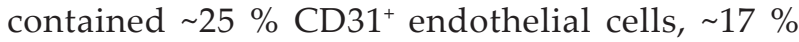
$\alpha-\mathrm{SMA}^{+}$perivascular cells, $\sim 8 \% \mathrm{ASAM}^{+}$adipocytes, as well as, $\sim 51 \%, \sim 8 \%$ and $\sim 8 \%$ cells expressing the stromal/stem cell surface markers CD29, CD90 and CD117, respectively (Table 1).

\section{Vascularisation of ad-MVF-seeded implants}

To analyse the in vivo vascularisation of HD, MD and LD ad-MVF-seeded Integra ${ }^{\circledR}$, a modified dorsal skinfold chamber model was used. This allowed for the repetitive visualisation and quantitative analysis of microvascular network formation by means of intravital fluorescence microscopy (Fig. 3a-i). The analyses revealed that the seeded ad-MVF were capable of developing interconnections with the surrounding host microvasculature of the fullthickness skin defects. This resulted in the onset of blood perfusion within the implanted matrices on day 6 (Fig. 3j). Throughout the following observation period, the density of perfused microvessels progressively increased (Fig. 3k). This was associated with typical signs of vascular maturation and remodelling, i.e. decrease of diameters, as well as, increase of centreline RBC velocities and wall shear rates of individual microvessels (Table 2). Of interest, this vascularisation process was comparable in the groups of HD and MD ad-MVF-seeded Integra ${ }^{\circledR}$ without significant differences in all measured morphological and microhaemodynamic parameters (Fig. 3j,k; Table 2). In contrast, LD ad-MVF-seeded matrices exhibited a reduced vascularisation with a lower number of perfused ROIs and functional microvessel density between day 6 and 14 after implantation (Fig. 3j,k).

Of interest, the vascularisation process also included haemorrhagic bleeding within the implants (Fig. 4a-g), which correlated with the extent of vascularisation and could be particularly observed during the phase of microvascular network development. Accordingly, HD and MD ad-MVFseeded Integra ${ }^{\circledR}$ exhibited elevated haemorrhagic scores on day 6 and 10, when compared to LD adMVF-seeded implants (Fig. 4g).

Table 1. Cellular expression (\%) of CD31, $\alpha$-SMA, ASAM, CD29, CD90 and CD117 in ad-MVF isolated from the epididymal fat pads of 7-12 months old $\mathrm{GFP}^{+}$donor mice ( $n=3$ per group), as assessed by flow cytometric analysis. Results are shown as mean $\pm \mathrm{SEM}$.

\begin{tabular}{|c|c|c|c|c|c|c|}
\hline $\begin{array}{c}\text { Age } \\
\text { (months) }\end{array}$ & CD31 & $\alpha$-SMA & ASAM & CD29 & CD90 & CD117 \\
\hline 7 & $30.0 \pm 1.8$ & $16.1 \pm 1.4$ & $9.1 \pm 0.9$ & $48.3 \pm 3.6$ & $9.1 \pm 1.0$ & $7.9 \pm 0.6$ \\
\hline 8 & $27.4 \pm 1.6$ & $19.8 \pm 1.8$ & $5.1 \pm 0.3$ & $51.0 \pm 2.5$ & $7.2 \pm 1.1$ & $6.4 \pm 1.1$ \\
\hline 9 & $25.7 \pm 0.9$ & $15.5 \pm 1.6$ & $7.8 \pm 1.0$ & $50.3 \pm 3.7$ & $7.1 \pm 0.5$ & $7.2 \pm 0.6$ \\
\hline 10 & $23.9 \pm 5.1$ & $14.8 \pm 2.5$ & $9.7 \pm 1.7$ & $57.7 \pm 2.8$ & $9.8 \pm 1.4$ & $10.8 \pm 1.5$ \\
\hline 11 & $20.8 \pm 0.5$ & $16.4 \pm 2.1$ & $8.4 \pm 0.5$ & $44.9 \pm 5.1$ & $8.0 \pm 0.8$ & $6.9 \pm 0.7$ \\
\hline 12 & $24.7 \pm 4.7$ & $20.1 \pm 1.7$ & $6.6 \pm 1.7$ & $51.2 \pm 7.4$ & $7.9 \pm 1.2$ & $8.6 \pm 1.9$ \\
\hline
\end{tabular}



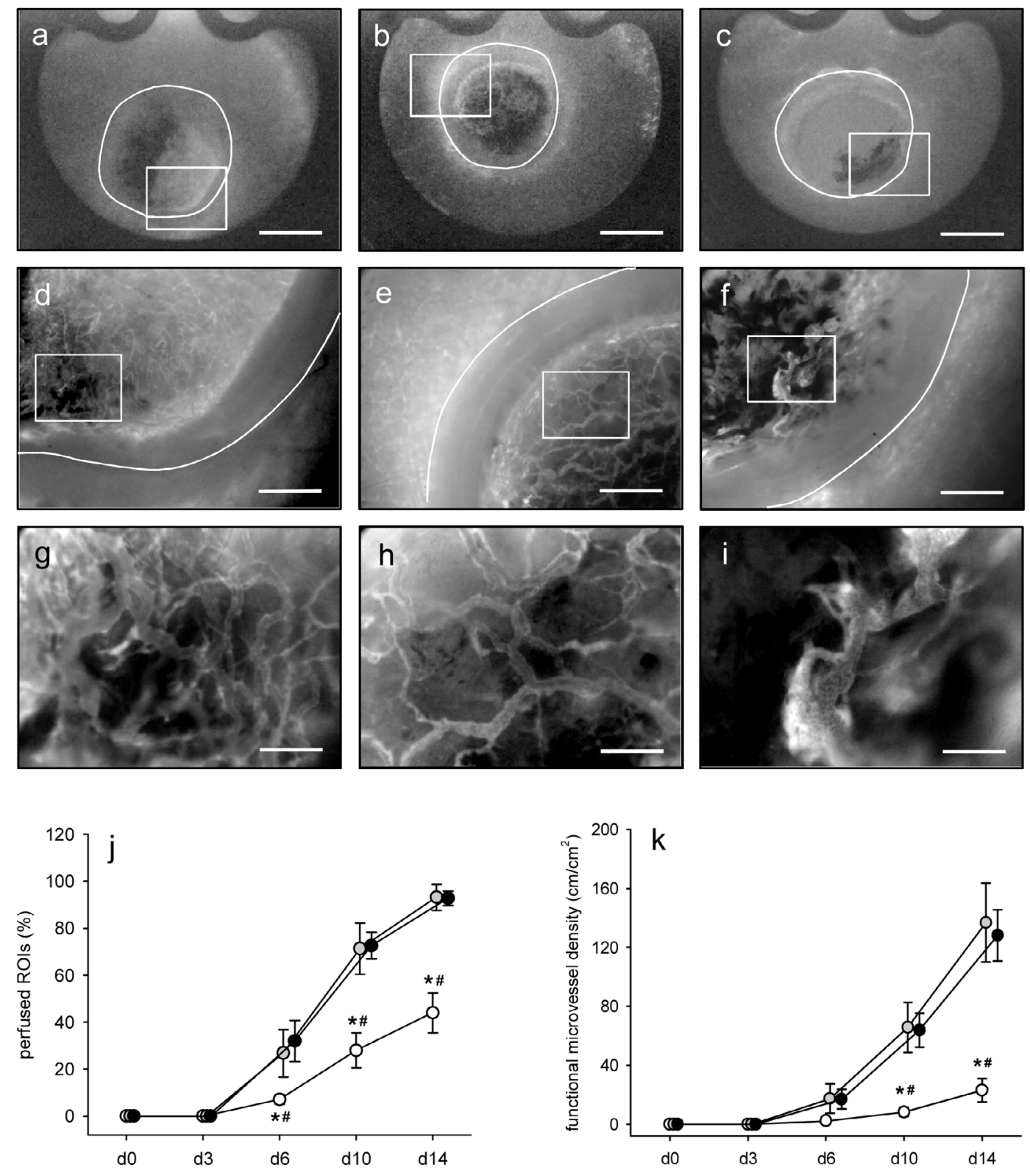

Fig. 3. (a-i) Intravital fluorescence microscopy (blue light epi-illumination, contrast enhancement by $5 \%$ FITC-labelled dextran) of $(\mathbf{a}, \mathbf{d}, \mathbf{g}) \mathrm{HD},(\mathbf{b}, \mathbf{e}, \mathbf{h}) \mathrm{MD}$ and $(\mathbf{c}, \mathbf{f}, \mathbf{i})$ LD ad-MVF-seeded Integra ${ }^{\circledR}$ on day 14 after implantation into full-thickness skin defects within dorsal skinfold chambers of C57BL/6 mice (a-c: overview of chamber observation window; d-f: higher magnification of inserts in a-c; g-i: higher magnification of inserts in $\mathbf{d}-\mathbf{f}$ ). Note that the HD and MD ad-MVF-seeded implants exhibit a higher vascularisation when compared to the $L D$ ad-MVF-seeded implant. Scale bars: $\mathbf{a}-\mathbf{c}=2.2 \mathrm{~mm} ; \mathbf{d}-\mathbf{f}=500 \mu \mathrm{m}$; g-i $=125 \mu \mathrm{m}$. (j) Perfused ROIs (\%) and (k) functional microvessel density $\left(\mathrm{cm} / \mathrm{cm}^{2}\right)$ of HD (black circles, $n=8$ ), MD (grey circles, $n=8$ ) and LD (white circles, $n=8$ ) ad-MVF-seeded Integra ${ }^{\circledR}$, as assessed by intravital fluorescence microscopy and computer-assisted image analysis. Means \pm SEM. ${ }^{*} p<0.05$ vs. HD ad-MVF-seeded Integra ${ }^{\circledR} ; " p<0.05$ vs. MD ad-MVF-seeded Integra ${ }^{\circledR}$. 
Table 2. Diameter $(\mu \mathrm{m})$, centreline RBC velocity $(\mu \mathrm{m} / \mathrm{s})$ and wall shear rate $\left(\mathrm{s}^{-1}\right)$ of microvessels in HD $(n=8), \mathrm{MD}(n=8)$ and LD $(n=8)$ ad-MVF-seeded Integra ${ }^{\circledR}$, as assessed by intravital fluorescence microscopy and computer-assisted image analysis. Results are shown as mean $\pm \mathrm{SEM}$.

\begin{tabular}{|c|c|c|c|c|c|}
\hline & d 0 & d 3 & d 6 & d 10 & d 14 \\
\hline \multicolumn{6}{|c|}{ Diameter $[\mu \mathrm{m}]:$} \\
\hline HD & - & - & $31.5 \pm 1.0$ & $23.5 \pm 1.7$ & $17.2 \pm 1.2$ \\
\hline MD & - & - & $31.7 \pm 1.8$ & $24.1 \pm 1.5$ & $19.5 \pm 1.4$ \\
\hline LD & - & - & $28.9 \pm 0.5$ & $22.5 \pm 0.6$ & $21.2 \pm 0.9$ \\
\hline \multicolumn{6}{|c|}{ Centreline RBC velocity $[\mu \mathrm{m} / \mathrm{s}]:$} \\
\hline HD & - & - & $229.2 \pm 51.0$ & $450.5 \pm 58.5$ & $497.6 \pm 78.9$ \\
\hline $\mathrm{MD}$ & - & - & $176.2 \pm 53.5$ & $419.6 \pm 78.3$ & $438.8 \pm 100.9$ \\
\hline LD & - & - & $148.1 \pm 50.7$ & $302.5 \pm 36.1$ & $392.4 \pm 66.8$ \\
\hline \multicolumn{6}{|c|}{ Wall shear rate $\left[\mathrm{s}^{-1}\right]$ : } \\
\hline $\mathrm{HD}$ & & - & $58.8 \pm 13.0$ & $141.0 \pm 17.8$ & $243.2 \pm 47.8$ \\
\hline $\mathrm{MD}$ & & - & $42.6 \pm 11.8$ & $137.5 \pm 20.6$ & $187.9 \pm 45.1$ \\
\hline LD & & - & $107.6 \pm 12.8$ & $151.2 \pm 30.3$ & $151.2 \pm 30.3$ \\
\hline
\end{tabular}

In addition, ad-MVF-seeded matrices were analysed by means of ultrasound and photoacoustic imaging, which allowed for the evaluation of the samples' oxygenation. In line with the different seeding densities, $\mathrm{sO}_{2}$ levels were highest in freshly HD ad-MVF-seeded, non-implanted matrices (Fig. $5 \mathrm{a}-\mathrm{g})$. After the $14 \mathrm{~d}$ vascularisation period within the dorsal skinfold chamber model, LD ad-MVF-seeded Integra ${ }^{\circledR}$ exhibited significantly lower $\mathrm{sO}_{2}$ levels when compared to HD ad-MVF-seeded samples (Fig. 5hn). Noteworthy, there were no significant differences between HD and MD ad-MVF-seeded implants (Fig. 5n).

\section{Incorporation and immune cell infiltration of ad- MVF-seeded implants}

At the end of the $14 \mathrm{~d}$ observation period, histological and immunohistochemical analyses were performed to study the incorporation of the ad-MVF-seeded implants. HE-stained sections of LD ad-MVF-seeded Integra ${ }^{\circledR}$ exhibited a dense vascularised granulation tissue within the border zones, whereas the centre of the implants only contained a few single cells (Fig. 6e,f). In contrast, in HD and MD ad-MVFseeded implants a dense tissue infiltration could not exclusively be observed in the border but also in the centre zones (Fig. 6a-d). The analysis of sirius redstained sections revealed that LD ad-MVF-seeded Integra ${ }^{\circledR}$ contained significantly less collagen fibres when compared to HD and MD ad-MVF-seeded samples (Fig. 6g-k). Taken together, these findings indicated an insufficient incorporation of LD adMVF-seeded implants into the surrounding host tissue.

In line with our intravital fluorescent microscopic results, the density of $\mathrm{CD} 31^{+}$microvessels was significantly lower in LD ad-MVF-seeded Integra ${ }^{\circledR}$ when compared to HD and MD ad-MVF-seeded matrices (Fig. 61-o). Of interest, $\mathrm{CD}^{+} 1^{+} / \mathrm{GFP}^{+}$costaining on day 14 demonstrated that $\sim 90 \%$ of all detected microvessels in HD, MD and LD ad-MVF- seeded implants originated from $\mathrm{GFP}^{+}$ad-MVF (Fig. 6p-s). Additional immunohistochemical stainings revealed that the implants were infiltrated with $\mathrm{MPO}^{+}$ neutrophilic granulocytes, CD68 ${ }^{+}$macrophages and, to a smaller extent, $\mathrm{CD}^{+}$lymphocytes (Fig. 7a-1). In accordance with their overall reduced cellular infiltration, LD ad-MVF-seeded matrices contained significantly smaller numbers of these immune cell subpopulations when compared to the HD and MD ad-MVF-seeded implants (Fig. 7j-1).

\section{Epithelialisation of the ad-MVF-seeded implants}

The continuous access to the ad-MVF-seeded matrices through the observation window of the dorsal skinfold chamber allowed for the repetitive stereomicroscopic analysis of implant epithelialisation (Fig. 8a-f). HD and MD ad-MVF-seeded Integra ${ }^{\circledR}$ exhibited a comparable epithelialisation over time while the epithelialised surface of LD ad-MVF-seeded Integra ${ }^{\circledR}$ was significantly less on days 10 and 14 (Fig. 8g). Immunohistochemical analyses on day 14 confirmed these findings. Only 57 \% of LD ad-MVF-seeded Integra $^{\circledR}$ were covered with a cytokeratin ${ }^{+}$epithelial layer, whereas the cytokeratin ${ }^{+}$epithelial coverage of HD and MD ad-MVF-seeded implants was 75 \% (Fig. 8h-k).

\section{Discussion}

Autologous STSG is the gold standard for the coverage of excised burn wounds (Supp et al., 2005; Kneilling et al., 2011; Kanapathy et al., 2016). For this purpose, a well-vascularised wound bed is an indispensable requirement (Schultz et al., 2003). In a promising experimental approach, we could recently demonstrate that this can be achieved by the implantation of ad-MVF-seeded dermal substitutes, which induce the formation of new microvascular networks at the defect site (Frueh et al., 2017a). In fact, seeding of $\sim 120,000$ ad-MVF $/ \mathrm{cm}^{2}$ Integra ${ }^{\circledR}$, 

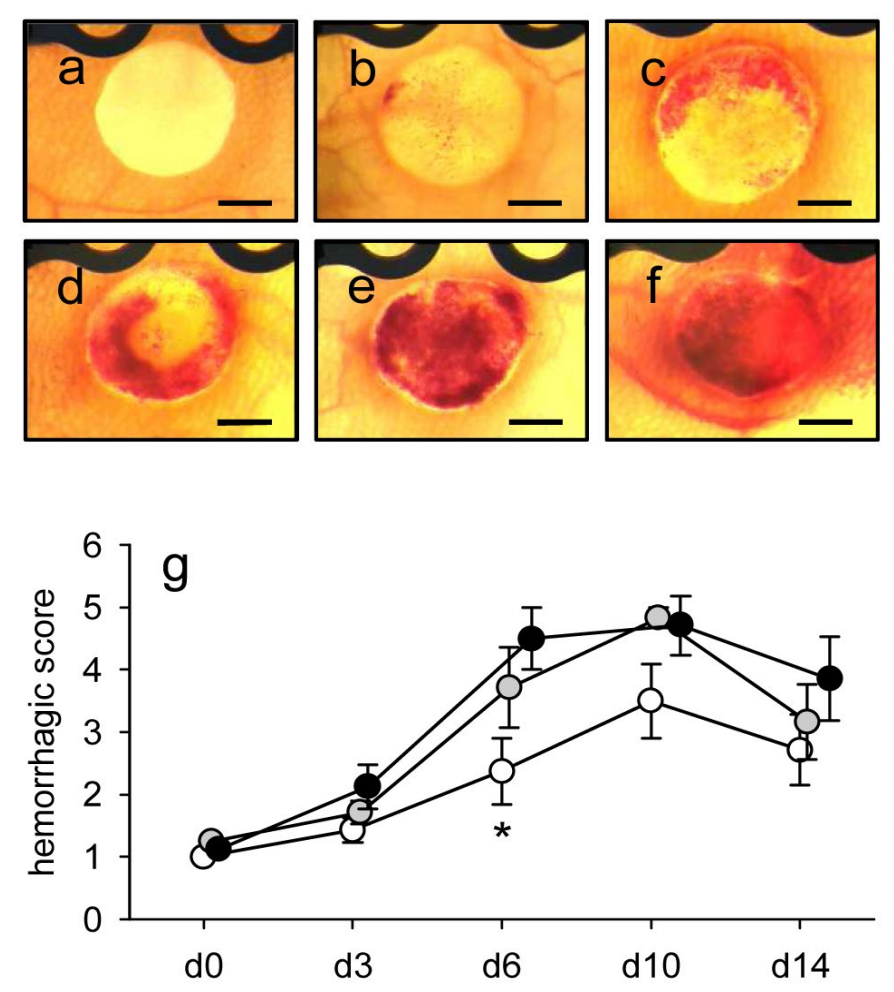

Fig. 4. (a-f) Transillumination stereomicroscopy of implanted ad-MVF-seeded Integra ${ }^{\circledR}$ within the dorsal skinfold chamber of C57BL/6 mice displaying different manifestations of implantinduced bleedings according to the semiquantitative haemorrhagic score, i.e. 1: no bleeding (a), 2: 1-25\% (b), 3: 26-50 \% (c), 4: 51-75\% (d), 5: 76-100\% (e), 6: bleeding exceeding implant surface (f). Scale bars: $1.3 \mathrm{~mm}$. (g) Haemorrhagic score of HD (black circles, $n=8$ ), MD (grey circles, $n=8$ ) and LD (white circles, $n=8$ ) ad-MVF-seeded Integra ${ }^{\circledR}$, as assessed by stereomicroscopy and computer-assisted image analysis. Means \pm SEM. ${ }^{*} p<0.05$ vs. HD ad-MVF-seeded Integra ${ }^{\circledR}$.
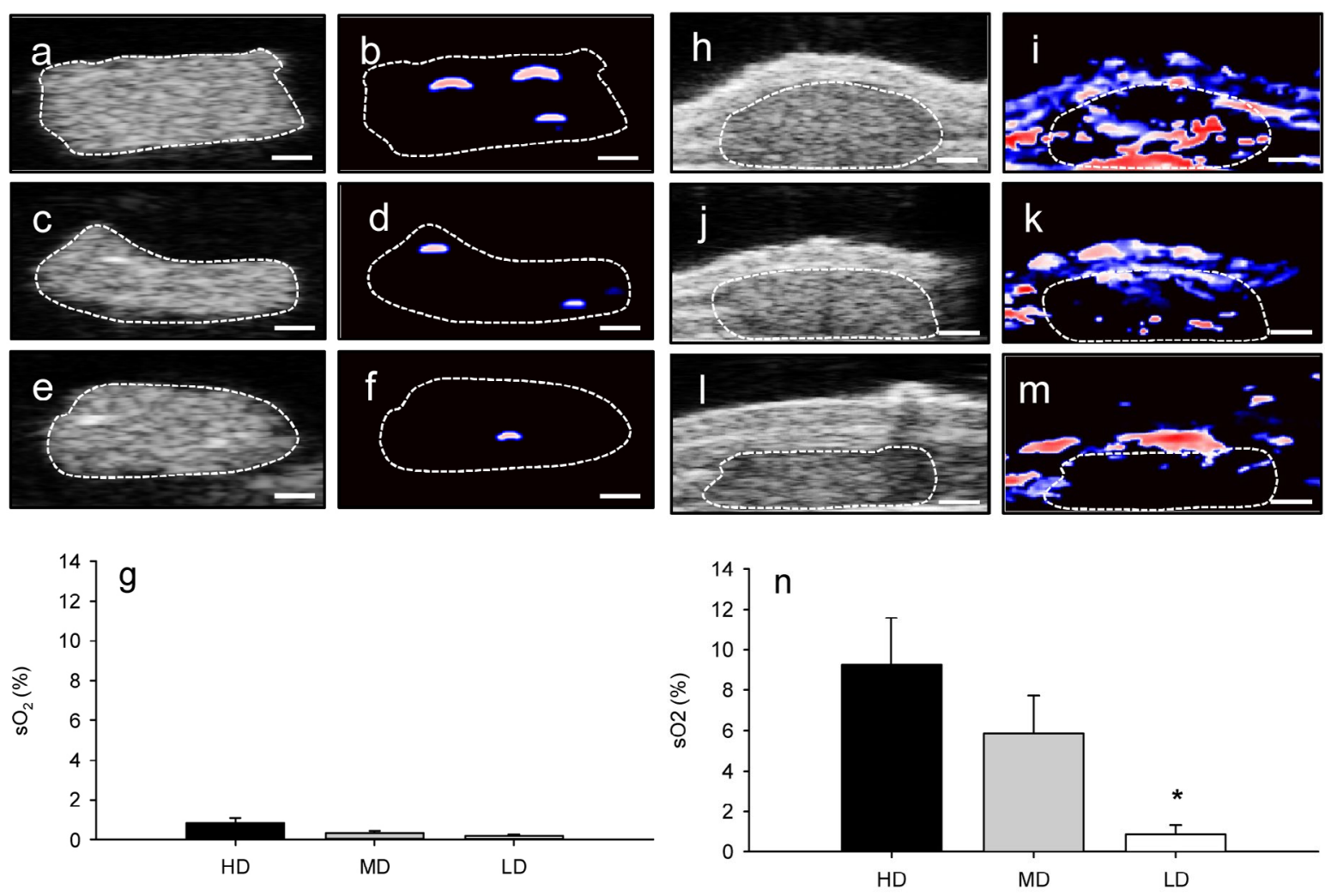

Fig. 5. (a,c,e) B-mode ultrasound and (b,d,f) OxyHemo-mode photoacoustic imaging of (a,b) HD,(c,d) MD and (e,f) LD ad-MVF-seeded Integra ${ }^{\circledR}$ directly after the seeding procedure $(\mathbf{b}, \mathbf{d}, \mathbf{f}$; red areas $=$ high oxygenation, blue areas = low oxygenation). Scale bars: $600 \mu \mathrm{m}$. (g) $\mathrm{sO}_{2}$ (\%) within freshly HD (black bar, $n=3$ ), MD (grey bar, $n=3$ ) and LD (white bar, $n=3$ ) ad-MVF-seeded Integra ${ }^{\circledR}$. Means \pm SEM. (h,j,l) B-mode ultrasound and (i,k, $\mathbf{m})$ OxyHemo-mode photoacoustic imaging of $(\mathbf{h}, \mathbf{i}) \mathrm{HD},(\mathbf{j}, \mathbf{k}) \mathrm{MD}$ and $(\mathbf{l}, \mathbf{m})$ LD ad-MVF-seeded Integra ${ }^{\circledR}$ on day 14 after implantation into full-thickness skin defects within dorsal skinfold chambers of C57BL/6 mice $(\mathbf{1}, \mathbf{k}, \mathbf{m}$; red areas = high oxygenation, blue areas = low oxygenation). Scale bars: $600 \mu \mathrm{m}$. (n) $\mathrm{sO}_{2}$ (\%) within HD (black bar, $n=3$ ), MD (grey bar, $n=3$ ) and LD (white bar, $n=3$ ) ad-MVF-seeded Integra ${ }^{\circledR}$ on day 14 after implantation. Means \pm SEM. ${ }^{*} p<0.05$ vs. HD ad-MVF-seeded Integra ${ }^{\circledR}$. 

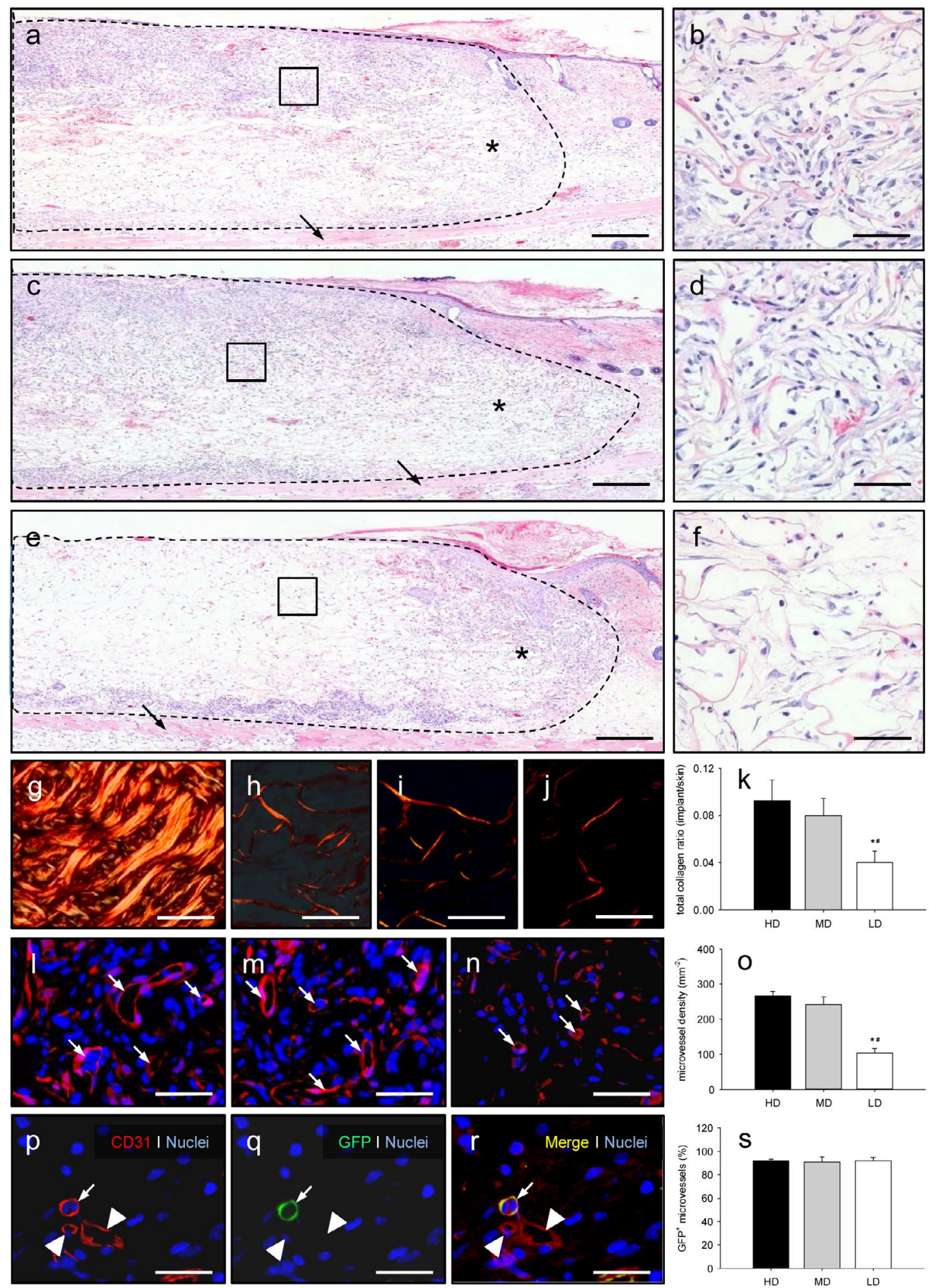

Fig. 6. HE-stained sections of $(\mathbf{a}, \mathbf{b}) \mathrm{HD},(\mathbf{c}, \mathbf{d}) \mathrm{MD}$ and $(\mathbf{e}, \mathbf{f})$ LD ad-MVF-seeded Integra ${ }^{\circledR}$ on day 14 after implantation into full-thickness skin defects within dorsal skinfold chambers of C57BL/6 mice (broken line = implant border; asterisks = border zones; arrows = panniculus carnosus muscle; $\mathbf{b}, \mathbf{d}, \mathbf{f}=$ inserts in $\mathbf{a}, \mathbf{c}, \mathbf{e})$. Scale bars: $\mathbf{a}, \mathbf{c}, \mathbf{e}=200 \mu \mathrm{m} ; \mathbf{b}, \mathbf{d}, \mathbf{f}=50 \mu \mathrm{m}$. (g-j) Polarised light microscopy of sirius red-stained sections of $(\mathbf{g})$ normal skin, as well as, (h) HD, (i) LM and (j) LD ad-MVF-seeded Integra ${ }^{\circledR}$ on day 14 after implantation. Scale bars $=45 \mu \mathrm{m}$. (k) Total collagen ratio (implant/skin) within HD (black bar, $n=8$ ), MD (grey bar, $n=8$ ) and LD (white bar, $n=8$ ) ad-MVF-seeded Integra ${ }^{\circledR}$. Means \pm SEM. $^{*} p<0.05$ vs. HD ad-MVF-seeded Integra ${ }^{\circledR}$; ${ }^{\#} p<0.05$ vs. MD ad-MVF-seeded Integra ${ }^{\circledR}$. (1-n) Immunohistochemical detection of CD $31^{+}$microvessels (arrows) in (1) HD, (m) MD and (n) LD ad-MVF-seeded Integra ${ }^{\circledR}$ on day 14 after implantation. Scale bars $=45 \mu \mathrm{m}$. (o) Microvessel density $\left(\mathrm{mm}^{-2}\right)$ within HD (black bar, $\left.n=8\right)$, MD (grey bar, $\left.n=8\right)$ and LD (white bar, $n=8$ ) ad-MVF-seeded Integra ${ }^{\circledR}$ on day 14 after implantation. Means \pm SEM. ${ }^{*} p<0.05$ vs. HD ad-MVFseeded Integra ${ }^{\circledR} ;{ }^{\sharp} p<0.05$ vs. MD ad-MVF-seeded Integra ${ }^{\circledR}$. (p-r) Immunohistochemical detection of CD31 ${ }^{+}$ $\mathrm{GFP}^{+}$microvessels (arrows) in a HD ad-MVF-seeded implant (arrowheads $=$CD31 $/$GFP- microvessels). Scale bars: $45 \mu \mathrm{m}$. (s) GFP' microvessels (\%) within HD (black bar, $n=8$ ), MD (grey bar, $n=8$ ) and LD (white bar, $n=8)$ ad-MVF-seeded Integra ${ }^{\circledR}$ on day 14 after implantation. Means \pm SEM. 


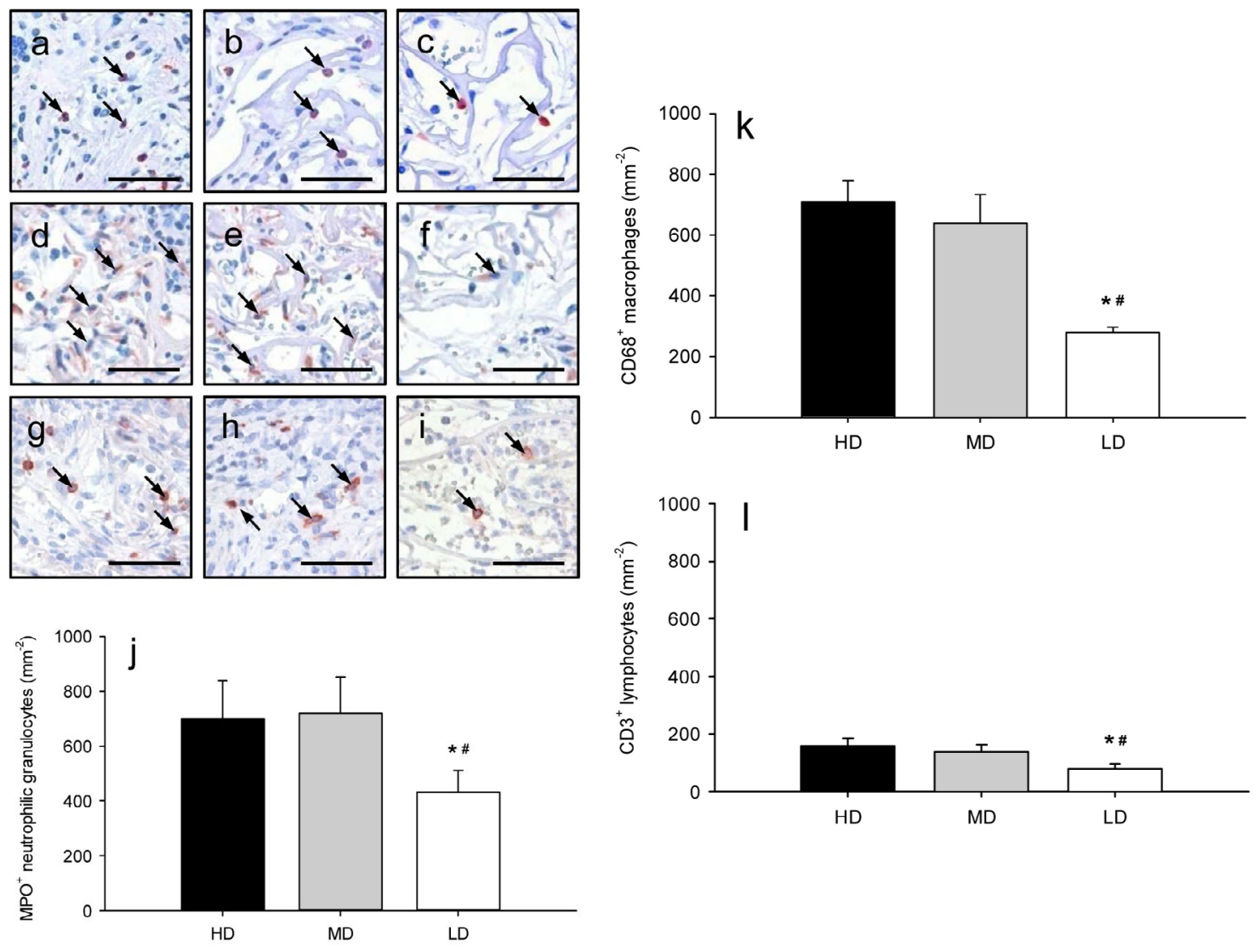

Fig. 7. Immunohistochemical detection of (a-c; arrows) $\mathrm{MPO}^{+}$neutrophilic granulocytes, (d-f; arrows) CD68 ${ }^{+}$ macrophages and (g-i; arrows) CD3 ${ }^{+}$lymphocytes in $(\mathbf{a}, \mathbf{d}, \mathbf{g}) \mathrm{HD},(\mathbf{b}, \mathbf{e}, \mathbf{h}) \mathrm{MD}$ and $(\mathbf{c}, \mathbf{f}, \mathbf{i})$ LD ad-MVF-seeded Integra ${ }^{\circledR}$ on day 14 after implantation into full-thickness skin defects within dorsal skinfold chambers of C57BL/6 mice. Scale bars $=24 \mu \mathrm{m}$. (j) $\mathrm{MPO}^{+}$neutrophilic granulocytes $\left(\mathrm{mm}^{-2}\right),(\mathbf{k}) \mathrm{CD}^{+} 8^{+}$macrophages $\left(\mathrm{mm}^{-2}\right)$ and $(\mathbf{l}) \mathrm{CD}^{+}$lymphocytes $\left(\mathrm{mm}^{-2}\right)$ within HD (black bars, $\left.n=8\right)$, MD (grey bars, $n=8$ ) and LD (white bars, $n=8$ ) ad-MVF-seeded Integra ${ }^{\circledR}$ on day 14 after implantation. Means \pm SEM. ${ }^{*} p<0.05$ vs. HD ad-MVF-seeded Integra ${ }^{\circledR} ; " p<0.05$ vs. MD ad-MVF-seeded Integra ${ }^{\circledR}$.

corresponding to the HD ad-MVF-seeded group of the present study, resulted in a rapid vascularisation and incorporation of the matrix after implantation into full-thickness skin defects (Frueh et al., 2017a). However, particularly in case of massive burn injuries affecting large surface areas of the body (Supp et al., 2005), the available amount of donor fat tissue for the isolation of ad-MVF may be limited. Taking this into account, our novel results demonstrated that a markedly reduced number of $\sim 80,000 \mathrm{ad}-\mathrm{MVF} / \mathrm{cm}^{2}$ Integra $^{\circledR}$, corresponding to the MD ad-MVF-seeded group, still allowed for a sufficient vascularisation and incorporation of the dermal substitute. In contrast, reducing the number to $40,000 \mathrm{ad}-\mathrm{MVF} / \mathrm{cm}^{2}$ Integra ${ }^{\circledR}$, corresponding to the LD ad-MVF-seeded group, resulted in an insufficient vascularisation and incorporation, as indicated by the lack of a dense vascularised granulation tissue in the centre of the substitute.

To guarantee the seeding of Integra ${ }^{\circledR}$ with welldefined ad-MVF densities, we first clarified whether individual mice markedly differ in terms of the amount of available epididymal adipose tissue and ad-MVF. We found that there were no significant differences between donor animals in the age range of 7-12 months. In addition, the isolated ad-MVF had a comparable average length and cellular composition. Of interest, the ad-MVF did not only contain CD31+ endothelial cells and $\alpha-\mathrm{SMA}^{+}$perivascular cells, but also cells expressing the stem cell surface markers CD90 and CD117, which have been reported to exhibit a high regenerative and angiogenic potential (Li et al., 2003; Li et al., 2005; Oishi and Ito-Dufros, 2006).

Ad-MVF seeded matrices were implanted into fullthickness skin defects within modified dorsal skinfold chambers. This approach provided deep insights into the vascularisation and incorporation process of the implants by combining sophisticated, noninvasive in vivo imaging technologies with additional histological and immunohistochemical analyses. Using intravital fluorescence microscopy, we found that $\mathrm{HD}$ and MD ad-MVF-seeded Integra ${ }^{\circledR}$ exhibited a comparable vascularisation over time, whereas LD ad-MVF-seeded implants were characterised by a significantly lower number of perfused ROIs and functional microvessel density. In line with these findings, additional photoacoustic measurements 
revealed lower $\mathrm{sO}_{2}$ levels within LD ad-MVF-seeded matrices on day 14 after implantation. Under clinical conditions, this reduced oxygenation may impair the engraftment of STSG. Taken together, these results clearly demonstrated that the seeding density isa crucial determinant for the in vivo vascularisation capacity of ad-MVF and their regenerative potential.

A high seeding density of ad-MVF promotes their reassembly into new microvascular networks (Später et al., 2017). This process not only involves the interconnection of individual ad-MVF with each other but also the development of anastomoses with the surrounding vessels of the host tissue. The latter mechanism results in the early onset of blood perfusion, while the newly forming microvascular networks within the ad-MVF-seeded implants have not been fully established yet and, thus, are characterised by an increased leakage of blood. In line with this view, the formation of haemorrhages within the implants of all three groups was most pronounced between day 6 and 10. Moreover, the delayed onset of blood perfusion in LD ad-MVF-seeded matrices was associated with less bleedings on day 6. On day 14, the extent of haemorrhages decreased again. This can be explained by a progressive stabilisation and maturation of the microvascular networks, as indicated by decreased diameters, as well as, increased centreline RBC velocities and wall shear rates of individual microvessels over time (Laschke et al., 2006).

Additional immunohistochemical analyses on day 14 showed that the pores of the centre of both HD and MD ad-MVF-seeded implants were filled with a vascularised granulation tissue, whereas the LD adMVF-seeded matrices mainly contained infiltrating single cells. As expected, LD ad-MVF-seeded implants also exhibited a significantly lower density of $\mathrm{CD}_{31}{ }^{+}$microvessels. However, the fraction of $\mathrm{GFP}^{+}$
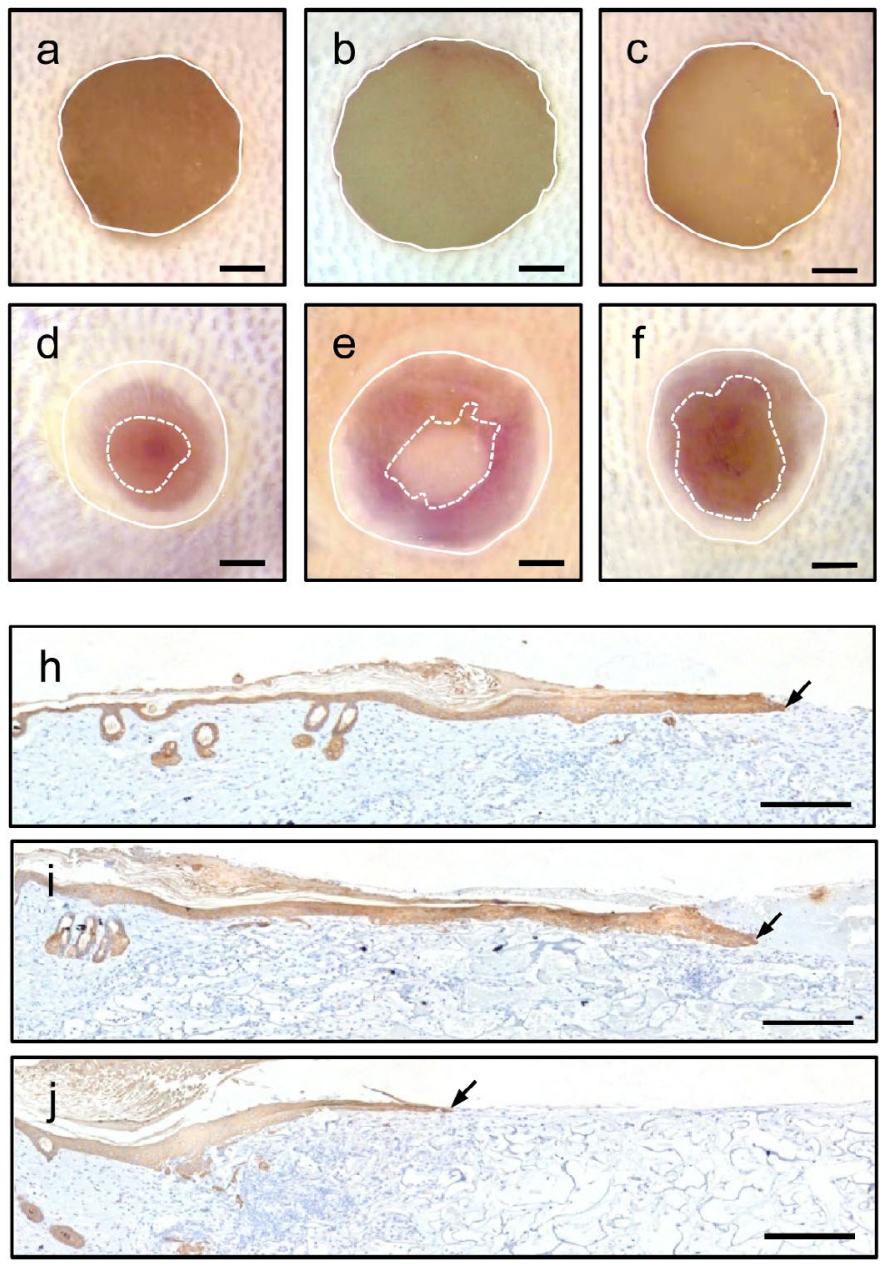
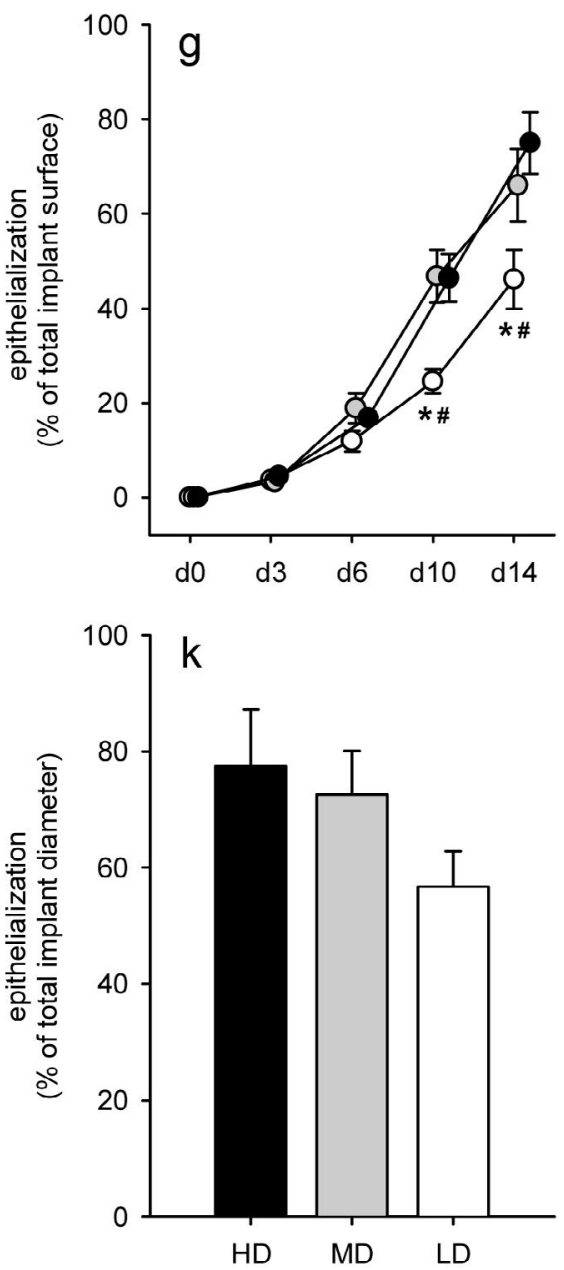

Fig. 8. Stereomicroscopic images displaying the epithelialisation of implanted (a,d) HD, (b,e) MD and (c, f) LD ad-MVF-seeded Integra ${ }^{\circledR}(\mathbf{a}-\mathbf{c})$ directly, as well as, (d-f) on day 14 after implantation. Scale bars: $750 \mu \mathrm{m}$. (g) Epithelialisation (\% of total implant surface) of HD (black circles, $n=8$ ), MD (grey circles, $n=8$ ) and LD (white circles, $n=8$ ) ad-MVF-seeded Integra ${ }^{\circledR}$, as assessed by planimetric analysis of stereomicroscopic images. Means \pm SEM. ${ }^{*} p<0.05$ vs. HD ad-MVF-seeded Integra ${ }^{\circledR} ;{ }^{\sharp} p<0.05$ vs. MD ad-MVF-seeded Integra ${ }^{\circledR}$. Immunohistochemical detection of the cytokeratin ${ }^{+}$epithelial layer (arrows) covering (h) HD, (i) MD and (j) LD ad-MVF-seeded Integra ${ }^{\circledR}$ on day 14 . Scale bars $=0.8 \mathrm{~mm}$. (k) Epithelialisation (\% of total implant diameter) of HD (black bar, $n=8$ ), MD (grey bar, $n=8$ ) and LD (white bar, $n=8$ ) ad-MVF-seeded Integra ${ }^{\circledR}$, as assessed by immunohistochemical analysis on day 14 after implantation. Means \pm SEM. 
microvessels was comparably high in all three groups. This proves that, even in the poorly vascularised LD ad-MVF-seeded implants, the vessel segments survived throughout the $14 \mathrm{~d}$ implantation period. On the other hand, this finding shows that less GFPmicrovessels of the surrounding host tissue invaded the matrices of this group. This positive correlation between a low ad-MVF seeding density and a reduced ingrowth of blood vessels may be explained by decreased levels of pro-angiogenic growth factors, such as vascular endothelial growth factor (VEGF) and basic fibroblast growth factor (bFGF), within the implants. In fact, isolated ad-MVF have previously been shown to release relevant amounts of these factors, which may markedly contribute to their high angiogenic activity after in vivo implantation (Laschke et al., 2012). In this context, it should be considered that there is also a close link between angiogenesis and inflammation (Fiedler et al., 2006; DiPietro, 2016). Several studies have reported that pro-angiogenic factors can act as chemokines for the recruitment of immune cells (Khoury and Ziyadeh, 2011; Barbay et al., 2015). Accordingly, we detected relatively large numbers of $\mathrm{MPO}^{+}$neutrophilic granulocytes, $\mathrm{CD}^{+} 8^{+}$macrophages and $\mathrm{CD}^{+}$lymphocytes in $\mathrm{HD}$ and MD ad-MVF-seeded Integra ${ }^{\circledR}$. Since immune cell infiltration is a key event in wound healing (Reinke and Sorg, 2012) and adequate biomaterial integration (Anderson et al., 2008), this may have further contributed to the improved incorporation of HD and MD ad-MVF-seeded implants, which finally exhibited a higher collagen content and increased surface epithelialisation, when compared to LD adMVF-seeded Integra ${ }^{\circledR}$.

\section{Conclusions}

This study demonstrates that a reduction from 120,000 to 80,000 ad-MVF $/ \mathrm{cm}^{2}$ Integra $^{\circledR}$ does not affect the implant's vascularisation and incorporation. These novel findings underline the high vascularisation potential of ad-MVF and indicate that $33 \%$ less adipose tissue is required for the isolation of ad-MVF needed for a rapid and sufficient vascularisation of the implanted Integra ${ }^{\circledR}$. Under clinical conditions, this may be particularly relevant for the treatment of patients with extensive skin defects and/or limited availability of fat tissue.

\section{Acknowledgments}

We are grateful for the excellent technical assistance of Janine Becker and Caroline Bickelmann. This study was partly funded by a grant of the Deutsche Forschungsgemeinschaft (DFG-German Research Foundation)-LA 2682/7-1.

\section{References}

Ampofo E, Widmaier D, Montenarh M, Menger MD, Laschke MW (2016) Protein kinase CK2 regulates leukocyte-endothelial cell interactions during ischemia and reperfusion in striated skin muscle. Eur Surg Res 57: 111-124.

Anderson JM, Rodriguez A, Chang DT (2008) Foreign body reaction to biomaterials. Semin Immunol 20: 86-100.

Awad HA, Butler DL, Harris MT, Ibrahim RE, Wu Y, Young RG, Kadiyala S, Boivin GP (2000) In vitro characterization of mesenchymal stem cell-seeded collagen scaffolds for tendon repair: effects of initial seeding density on contraction kinetics. J Biomed Mater Res 51: 233-240.

Barbay V, Houssari M, Mekki M, Banquet S, Edwards-Lévy F, Henry JP, Dumesnil A, Adriouch S, Thuillez C, Richard V, Brakenhielm E (2015) Role of M2-like macrophage recruitment during angiogenic growth factor therapy. Angiogenesis 18: 191-200.

Böttcher-Haberzeth S, Biedermann T, Reichmann E (2010) Tissue engineering of skin. Burns 36: 450-460.

Debels H, Hamdi M, Abberton K, Morrison W (2015) Dermal matrices and bioengineered skin substitutes: a critical review of current options. Plast Reconstr Surg Glob Open 3: e284.

DiPietro LA (2016) Angiogenesis and wound repair: when enough is enough. J Leukoc Biol 100: 979-984.

Fiedler U, Reiss Y, Scharpfenecker M, Grunow V, Koidl S, Thurston G, Gale NW, Witzenrath M, Rosseau S, Suttorp N, Sobke A, Herrmann M, Preissner KT, Vajkoczy P, Augustin HG (2006) Angiopoietin-2 sensitizes endothelial cells to TNF-alpha and has a crucial role in the induction of inflammation. Nat Med 12: 235-239.

Frueh FS, Später T, Lindenblatt N, Calcagni M, Giovanoli P, Scheuer C, Menger MD, Laschke MW (2017a) Adipose tissue-derived microvascular fragments improve vascularization, lymphangiogenesis, and integration of dermal skin substitutes. J Invest Dermatol 137: 217-227.

Frueh FS, Später T, Scheuer C, Menger MD, Laschke MW (2017b) Isolation of murine adipose tissuederived microvascular fragments as vascularization units for tissue engineering. J Vis Exp 122: DOI: $10.3791 / 55721$.

Graham GP, Helmer SD, Haan JM, Khandelwal A (2013) The use of Integra ${ }^{\circledR}$ Dermal Regeneration Template in the reconstruction of traumatic degloving injuries. J Burn Care Res 34: 261-266.

Grässer C, Scheuer C, Parakenings J, Tschernig T, Eglin D, Menger MD, Laschke MW (2016) Effects of macrophage-activating lipopeptide-2 (MALP-2) on the vascularisation of implanted polyurethane scaffolds seeded with microvascular fragments. Eur Cell Mater 32: 74-86.

Kanapathy M, Hachach-Haram N, Bystrzonowski N, Harding K, Mosahebi A, Richards T (2016) Epidermal grafting versus split-thickness skin 
grafting for wound healing (EPIGRAAFT): study protocol for a randomised controlled trial. Trials 17: 245.

Kneilling M, Breuninger H, Schippert W, Häfner HM, Moehrle M (2011) A modified, improved, easy and fast technique for split-thickness skin grafting. Br J Dermatol 165: 581-584.

Khoury CC, Ziyadeh FN (2011) Angiogenic factors. Contrib Nephrol 170: 83-92.

Laschke MW, Menger MD (2015) Adipose tissue-derived microvascular fragments: natural vascularization units for regenerative medicine. Trends Biotechnol 33: 442-448.

Laschke MW, Menger MD (2016) The dorsal skinfold chamber: a versatile tool for preclinical research in tissue engineering and regenerative medicine. Eur Cell Mater 32: 202-215.

Laschke MW, Elitzsch A, Vollmar B, Vajkoczy P, Menger MD (2006) Combined inhibition of vascular endothelial growth factor (VEGF), fibroblast growth factor and platelet-derived growth factor, but not inhibition of VEGF alone, effectively suppresses angiogenesis and vessel maturation in endometriotic lesions. Hum Reprod 21: 262-268.

Laschke MW, Kleer S, Scheuer C, Schuler S, Garcia P, Eglin D, Alini M, Menger MD (2012) Vascularisation of porous scaffolds is improved by incorporation of adipose tissue-derived microvascular fragments. Eur Cell Mater 24: 266-277.

Laschke MW, Kleer S, Scheuer C, Eglin D, Alini M, Menger MD (2015) Pre-cultivation of adipose tissuederived microvascular fragments in porous scaffolds does not improve their in vivo vascularisation potential. Eur Cell Mater 29: 190-200.

Li TS, Hamano K, Nishida M, Hayashi M, Ito H, Mikamo A, Matsuzaki M (2003) CD117+ stem cells play a key role in therapeutic angiogenesis induced by bone marrow cell implantation. Am J Physiol Heart Circ Physiol 285: H931-937.

Li TS, Ito H, Hayashi M, Furutani A, Matsuzaki M, Hamano K (2005) Cellular expression of integrin-beta 1 is of critical importance for inducing therapeutic angiogenesis by cell implantation. Cardiovasc Res 65: 64-72.

MacNeil S (2007) Progress and opportunities for tissue-engineered skin. Nature 445: 874-880.

Mallidi S, Watanabe K, Timerman D, Schoenfeld D, Hasan T (2015) Prediction of tumor recurrence and therapy monitoring using ultrasound-guided photoacoustic imaging. Theranostics 5: 289-301.

Miyanaga T, Haseda Y, Sakagami A (2016) Minced skin grafting for promoting epithelialization of the donor site after split-thickness skin grafting. Burns 43: 819-823.

Nunes SS, Krishnan L, Gerard CS, Dale JR, Maddie MA, Benton RL, Hoying JB (2010) Angiogenic potential of microvessel fragments is independent of the tissue of origin and can be influenced by the cellular composition of the implants. Microcirculation 17: 557-567.
Oishi K, Ito-Dufros Y (2006) Angiogenic potential of CD44+ CD90+ multipotent CNS stem cells in vitro. Biochem Biophys Res Commun 349: 1065-1072.

Reinke JM, Sorg H (2012) Wound repair and regeneration. Eur Surg Res 49: 35-43.

Rich LJ, Seshadri M (2015) Photoacoustic imaging of vascular hemodynamics: validation with blood oxygenation level-dependent MR imaging. Radiology 275: 110-118.

Schultz GS, Sibbald RG, Falanga V, Ayello EA, Dowsett C, Harding K, Romanelli M, Stacey MC, Teot L, Vanscheidt W (2003) Wound bed preparation: a systematic approach to wound management. Wound Repair Regen 11 Suppl 1: S1-28.

Shevchenko RV, James SL, James SE (2010) A review of tissue-engineered skin bioconstructs available for skin reconstruction. J R Soc Interface 7: 229-258.

Singer M, Korsh J, Predun W, Warfield D Jr, Huynh R, Davenport T, Riina L (2015) A novel use of integra ${ }^{\mathrm{TM}}$ bilayer matrix wound dressing on a pediatric scalp avulsion: a case report. Eplasty 15: e8.

Sorg H, Krueger C, Vollmar B (2007) Intravital insights in skin wound healing using the mouse dorsal skin fold chamber. J Anat 211: 810-818.

Sorg H, Krueger C, Schulz T, Menger MD, Schmitz F, Vollmar B (2009) Effects of erythropoietin in skin wound healing are dose related. FASEB J 23: 30493058.

Später T, Frueh FS, Metzger W, Menger MD, Laschke MW (2016) In vivo biocompatibility, vascularization, and incorporation of Integra ${ }^{\circledR}$ dermal regenerative template and flowable wound matrix. J Biomed Mater Res B Appl Biomater. DOI: 10.1002/ jbm.b.33813.

Später T, Frueh FS, Menger MD, Laschke MW (2017) Potentials and limitations of Integra ${ }^{\circledR}$ flowable wound matrix seeded with adipose tissue-derived microvascular fragments. Eur Cell Mater 33: 268-278.

Supp DM, Steven T. Boyce ST (2005) Engineered skin substitutes: practices and potentials. Clin Dermatol 23: 403-412.

Trottier V, Marceau-Fortier G, Germain L, Vincent C, Fradette J (2008) IFATS collection: using human adipose-derived stem/stromal cells for the production of new skin substitutes. Stem Cells 26: 2713-2723.

Utzinger U, Baggett B, Weiss JA, Hoying JB, Edgar LT (2015) Large-scale time series microscopy of neovessel growth during angiogenesis. Angiogenesis 18: 219-232.

Wisser D, Steffes J (2003) Skin replacement with a collagen based dermal substitute, autologous keratinocytes and fibroblasts in burn trauma. Burns 29: 375-380.

Zhong SP, Zhang YZ, Lim CT (2010) Tissue scaffolds for skin wound healing and dermal reconstruction. Wiley Interdiscip Rev Nanomed Nanobiotechnol 2: 510-525. 


\section{Discussion with Reviewers}

Daniel Schmauss: Do you think there might be differences between the fat harvesting zones of the human body (e.g. abdomen, thigh, flanks) regarding the quality/usability of the fat for microvascular fragments?

Authors: Subcutaneous white fat tissue generally exhibits a dense vascularisation. Hence, although not further analysed so far, there may be no marked variations between different fat harvesting zones of the human body regarding the quality/usability of the fat for the isolation of microvascular fragments. Under clinical conditions, the fat harvesting zone may even be individually chosen according to the specific needs of the patient. In most cases it may be liposuctioned fat from the abdominal wall.

Editor note: The scientific editor for this paper was Chris Evans. 